\title{
THE FORMATION OF THE FUTURE SPECIALIST PROFESSIONAL CULTURE IN THE EDUCATIONAL SPACE OF THE UNIVERSITY
}

\author{
Natalia Nikula ${ }^{1}$, Andriy Brazhaniuk ${ }^{2}$ \\ ${ }^{1}$ Candidate of Pedagocial Sciences, assistantat the Department of Pedagogy and Methods of Elementary \\ Education, at Yuriy Fedkovych Chernivtsi National University, Ukraine, e-mail: n.nikyla07@gmail.com \\ ${ }^{2}$ Assistant of Human Health, Recreation and Fitness Department, at Yuriy Fedkovych Chernivtsi National \\ University, Ukraine, e-mail: big-bra@bigmir.net
}

\begin{abstract}
The article highlights the theoretical foundations on the formation of future specialist professional culture the in the field of professions "person-person». It is established that this is a purposeful, specially organized influence on the individual to improve his/her motivational sphere, value orientations, professional knowledge, skills and abilities, ability to empathy and reflection. This problem was studied by the author from the view of several scientific approaches: axiological, cultural, competence, activity. Based on the definitive analysis, the "professional culture of a specialist» concept is formulated, which is considered as a combination of professional and personal values and qualities of a specialist, his/her professional competence, which ensure highly effective fulfilment of professional duties based on reflection and self-development. Structural and semantic analysis allowed identifying components of the professional culture of future professionals i.e. value, cognitive, personal, and reflexive. The experimental research diagnostic tools of a formation condition of the future specialist professional culture in educational space of university are developed and tested: criteria, indicators, levels, techniques which reflect integrity of the investigated phenomenon structural components. The organizational and pedagogical conditions for the formation of the professional culture of the future specialist in the field of professions "person-person», which were implemented in the educational environment of the university, have been developed and theoretically grounded. An experimental study was fulfilled and the effectiveness of the proposed organizational and pedagogical conditions was proved.
\end{abstract}

Keywords: culture, professional culture, values, competence, conditions.

JEL Classification: I24, I29

Formulas: 0; fig.: 1; tabl.: 0; bibl.: 35

Introduction. Nowadays, when the world is suffering from a pandemic caused by the acute respiratory disease COVID-19, various industries are being tested, and education is no exception. Quarantine has become a challenge not only for the Ukrainian education system, but also for education around the world. The question of the organization of the educational process in the conditions of the quarantine in various educational institutions (starting from preschool institutions and finishing with higher education institutions) became acute. Scientists around the world, including Fernando M.Reimers (2020), the Global Education Innovation Initiative, the Harvard Graduate School of Education Andreas Schleicher (2020), the Directorate of Education and Skills, the Organization for Economic Cooperation and Development, and within PISA are discussing distance education. Representatives of the international organization UNESCO (Press Service, 2010) are also deeply concerned and highlight a list of problems related to the transition to distance learning. Accordingly, the challenges of the XXI century actualize the problem of training a specialist in the educational space of the university, which have to master professional values, positive personal qualities, professional competence, ability to empathize and reflection, synthesized in the professional culture of the specialist. An 
individual working in the field of occupations «person-person» will be able to provide qualitative and professional services in any mode: the usual or in quarantine i.e. distant.

The normative documents of the educational system of Ukraine, in particular the Law of Ukraine «On Education» (2017), «On Higher Education» (2014) emphasize the transformation and formation of the specialist's culture who integrates professional knowledge, skills, personal values and qualities, ability to reflections, the desire for self-education and self-development. The formation of two last qualities plays a significant role, because educators in the present conditions have mastered new technologies and tools for distance education. Thus, the specialist professional culture should be shown through the readiness to work both in usual conditions and in distance learning. That is why our publication reveals the conditions, forms and methods that are appropriate to use in the educational space of both the university and the distance mode.

Literature Review. The phenomenon of «culture» is very broad and meaningful, the history of its study dates back to antiquity. Various definitions according to this concept have been discovered by American scientists A. Kroeber and L. Kluckhohn (1952); the origin of the concept of «culture» and its transformation into education is described by M. Cato (1950); the reflection of the spiritual sphere in the culture notion is discussed in the work of $\mathrm{M}$. Cicero [5].

Today the concept of «culture» is studied from the point of various sciences: in philosophical science, the concept of «culture» is considered as a form of human activity to create, restore their social existence, material and spiritual values (Kornienko, 1998; Ognevyuk, 2003, Petinova, 2002); in sociological science, this concept is distinguished as a system of values, ideas about life and be havi our codes common to people (Tanchyn, 2007, Gerasymchuk, Palekha, Shyyan, 2004); in psychology, the phenomenon of «culture» was studied by many scientists, including R. Pavelkiv(2009), S. Rubinstein (1976), V. Rybalka (2009) who are interested in the influence of culture on the human psyche development, the formation of personality in different conditions; in pedagogical science, the concept of «culture» is mostly considered as a teacher's culture, pedagogical, professional culture which is revealed in the works of I. Zyazyun (2009) and others.

With the development of science, this concept has been transformed into the human personality and its activities, which is revealed in scientific works, in particular: the activity side of culture is revealed in the works of E. Markaryan (1983), V. Shadrykov (1998); culture is defined as a creative component of personality by the authors V. Bibler (1989) and I. Isayev (2010); the theory of the personality and activity culture is revealed in scientific works of N. Zlobin (1980), G. Filipchuk (2014).

Today, there are a number of scientific works devoted to the professional culture of the specialists: different professional culture was studied by Yu. Boychuk (2010), G. Sotska (2011); professional culture through the prism of education is investigated by the following scientists: T. Tarasenko (2014),V. Tereshchuk (2007); the 
professional culture formation of future specialists was studied by N. Krylova (1990), V. Slastyonin (1993) and others.

We also discover a number of scientific works where the problem of professional training is aimed at forming the future specialist culture in the field of "person-person": N. Nychkalo (2001), L. Khomych (1998) and others.

Considering the significant achievements of works that at the scientific level highlight various aspects of the described problem, we consider it necessary to fully investigate the problem of forming a professional culture of the specialist in the educational space of the university.

Aims. The aim of the article is a theoretical grounding and experimental verification of organizational and pedagogical conditions of the professional culture formation of the future specialist in the educational space of the university.

Methods. To achieve the aim and show the theoretical foundations of the problem of forming the future specialist professional culture in the educational environment of the university, we used the following methods:

- theoretical: analysis, comparison; study of legislative and regulatory documents; definitive analysis; structural and semantic analysis for determining the content and components of the future specialist professional culture;

- empirical: observation, questionnaires, testing, written survey to determine the level of formation of the future specialists' professional culture; pedagogical experiment (identifying, formative) i.e. to identify the effectiveness of our proposed organizational and pedagogical conditions for the formation of professional culture of the future specialist in the educational space of the university;

- methods of mathematical statistics were used to process and verify the results of the experiment using $x^{2}$ Pearson's test; automatic calculations of numerical data were performed using MS Excel;

- graphical methods were used to illustrate and compare the results of experimental work: diagrams, tables.

Results. Outcomes of theoretical research. By logic on scientific research, we consider it necessary to analyze the categorical framework of our study.

Nowadays, there are about 500 definitions of «culture». According to American cultural specialists, their number is constantly increasing. Ifwe consider scientific studies, from 1871 to 1919 there were 7 definitions of this concept, then from 1920 to 1950 their number increased to 157 [14], which indicates a scientific interest in this phenomenon, and about its diveersity and extreme complexity.

In general, today in philosophical science the concept of «culture» is understood as a form of human activity to create, restore their social existence, represented through the material and spiritual values development [13, p. 21].

In sociological science, this concept is considered as a system of values, ideas about life and codes of behaviour common to people associated with a particular way of life [30, p. 35].

In psychology, the phenomenon of «culture» has been studied by many scientists who are interested in the influence of culture on the development of the human psyche, the formation of personality in different conditions [21]. 
The phenomenon of our research, namely the «the specialist professional culture», is mostly studied in terms of education and pedagogy, as its formation takes place in the educational space of the university.

The concept of «professional culture», I. Isayev, defines it as the degree of mastery of members of the professional group techniques and methods of solving special professional tasks [9, p. 143]. According to O. Popenko (2012), professional culture involves the acquisition of professional knowledge, professional competence, and the formation of professionally significant qualities necessary for professional activity [23, p. 46].

We have studied the professional culture formation issueof a specialist from the standpoint of several scientific approaches: axiological, which view the culture as a system of the specialist values; cultural, as the personality cultural creation and activity of the specialist; competence, availability of a system of skills and abilities for the purpose of high-quality professional activity; activity, which allowed to consider this process as a complex, multifaceted, manageable and specially organized.

Thus, we have defined the concept of «specialist'sprofessional culture», which is regarded as a combination of professional and personal values and personal qualities, the professional competence, which ensures highly effective performance of professional duties based on reflection and self-development.

- valuable, which is revealed through has system professional and personal values and motives; this component expresses a conscious motivation to maintain professional activities and acts as a systemforming factor in the dynamic formation of future professionals professional culture in the field of «person-person».

- cognitive, which is represented by professional competence and skills to implement the acquired knowledge in practice; that is, this component combines the theoretical training of future professionals for professional activities and reflects the practical readiness to fulfil professional activities at the appropriate level;

- personal, which is manifested in the professionally significant qualities of the future specialist; this component gives the professional activity of future specialists a pronounced personal character, which is very important in the field of «personperson»;

- and reflexive, which is revealed throughself-assessment of the professional activities and the desire for self-development; in the basis of this component there is the skills and ability to reflection, which is revealed through self-knowledge, the essence knowledge, objects and results of their own professional activities.

We consider that the components of the future specialist professional culture are interrelated components and reflect the most important features of the personal and activity aspects of professional culture.

Based on the analysis of various educational documents, it is established that the formation of professional culture of future professionals occurs through a system of studying professionally-oriented disciplines and practical training. However, analysing the content, forms and methods of training future professionals in the field 
of «person-person» we have identified some gaps that violate the integrity of all components formation of the future professionals' professional culture.

To identify the formation level of professional culture of future professionals in the educational space, we have developed diagnostic tools for the experimental research in a condition of formation the professional culture of the expert in educational space of university are developed and tested: criteria, indicators, levels which reflect integrity of structural components of the investigated phenomenon.

Thus, the criteria are selected: professional and personal values and motives (value component); professional competence (cognitive component); professionally significant qualities (personal component); professional activity reflection and desire for self-development (reflexive component).

The levels of professional culture formation are determined, there are low, medium, sufficient, high.It is substantiated that the transition from the previous to the next level of formation of the professional culture of the future specialist in the educational space of the university occurs due to quantitative and qualitative changes in the components of the studied phenomenon.

To identify the formation level of each structural component of the professional culture of future professionals, we have selected a set of methods. Thus, the value orientations level of future professionals and the value component of their professional culture, we tested using the method by M. Rokych «Value Orientations» [16]. We investigated the level of the cognitive component, the formation of theoretical knowledge of future specialists with the help of author's test. The level of the personal component, and the formation of future professionals' empathy, we investigated using the method by I. Yusupov "Ability to empathy» [24]. We investigated the reflexive component, the ability to reflect, self-knowledge and selfdevelopment using the method by A. Karpov «Diagnosis of reflection» [10]. The results of the incoming statement allowed identifying the insufficient level of future specialists' professional culture in the educational space of the university, which caused the development and testing of experimental organizational and pedagogical conditions for the formation of professional culture of future specialists' training.

Before considering in detail the organizational and pedagogical conditions for the formation of professional culture of future specialists in the educational space of the university, we will define the genesis of this concept. Semantic analysis indicates its rather broad semantic meaning, among which in the context of our study scientific interest is the following: the condition is «the necessary circumstance that makes possible the implementation, creation, formation of something or contributes to something», "circumstances, features of reality, in which something happens or maintains», «rules that exist or are established in a particular area of life, activities that ensure the normal operation of something; rules, requirements, the implementation of which provides something», «a set of data, the provisions underlying something» [3, p. 617].

Analysing the scientific research, we find different conditions for the formation of future specialists. However, synthesizing scientific and pedagogical knowledge in the field of professional training, we have proposed the following organizational and 
pedagogical conditions for the formation of future specialists' professional culture in the educational space of the university in the field of «person-person»:

-improving the content of the formation of professional culture of the future specialist in the educational process of the institution;

-usingthe optimal organizational forms of improving the professional culture of the future specialist in the educational space of the university;

-combining the traditional and innovative methods of forming a professional culture;

-implementing self-educational activities of the future specialist on the formation of professional culture.

Showing the first organizational and pedagogical condition:improving the content of the formation of professional culture of the future specialising the educational process of the institution, we willanalyse the concept of «content», which in reference sources is considered as "what is said, told somewhere, what is described, depicted», «essence, the inner feature of something» [3]. The «content of education» means the structure, nature and a bulk of educational information, which mastering provides the opportunity for education.

We analysed the state standard, curricula, curricula of disciplines that provide theoretical and practical training for future professionals in the field of «person person». Therefore, the content of the formation of future specialists' professional culture will be considered as a scientifically sound methodological and didactic educational material, the assimilation of which provides the necessary level of knowledge, skills and abilities synthesized in the professional culture of professionals in the field of «person - person». This content underlies the organization of the educational process of higher education and is reflected in the disciplines of the professional training cycle. The analysis of these disciplines showed the lack of acquaintance of students with the essence and content of professional culture of future professionals as a holistic formation of its structural components. Therefore, we consider it necessary to supplement the content of training and introduce into the educational process of their training selective discipline «Professional culture of the specialist».

Also, the fulfilled analysis showed that the formation of professional culture of future specialists in the educational space of the university is carried out in part, in fragments, focusing mostly on its individual components. We believe that the formation of the valuable, reflexive and personal component is insufficient.

Thus, implementing this condition, we have supplemented the disciplines with additional topics or individual issues that ensure the holistic formation of professional culture and all its components. So, to form a value component, we offer training «My personal and professional values», a conversation on «The values of my life» and others. Also, for the formation of the cognitive component, we propose to supplement the content of educational material with lectures, which will acquaint students in more detail with the «culture» and «specialist culture» concepts. In particular, we offer the following topics for acquaintance: «Specialist culture», «Professional culture as a guarantee of successful activity», «The role of professional culture for 
professional growth», "What is reflection and what is its role in developing the specialist's professional culture».

We have offered the next organizational and pedagogical condition, they areusingthe optimal organizational forms of improving the professional culture of the future specialist in the educational space of the university. It is implemented through the use of various forms of the educational process organization in the educational space of the university.

Nowadays, the training of future professionals is carried out through the use of traditional forms, such as: lecture, seminar, practical training, laboratory training, etc. But times are changing, the requirements for specialists are another, and the conditions for organizing the educational process are changing, in particular the introduction of distance learning online. Taking into account these factors, we propose to diversify the forms of training for the formation of their professional culture:

- application of innovative types of lectures: binary, visualization lectures, interactive lectures, such types will ensure the formation of cognitive and reflexive components of the future specialists'professional culture in the field of «person person»;

- training is the technology of actions in the interactive form on the basis of a certain concept of reality; the use of such form will facilitate the application of acquired theoretical knowledge in practice in combination with professionally significant qualities of the specialist, which reflects the combination of his cognitive and personal component;

- workshop is an intensive educational event, in the process of which participants learn primarily through their own active work, during which the professional competence is formed, the ability to analyse their own professional activities, the ability to self-development is formed;

- conference is a form of organization, an event in which the analysis of current problems and theirsolution; presentation of new technologies, goal strategies or products; strengthening cooperation between different groups; increasing the motivation of participants; the value, cognitive component of professional culture of future specialists is formed;

- forum is an event attended by experts who represent different points of view, which are often the opposite of a particular problem, future professionals develop the ability to form and express their own point of view, their professional position, the ability to carry out professional reflection;

- webinar as a form of learning is becoming increasingly popular, its advantages are that you can participate at a convenient time for participants in the educational process, you can unite in the interests of future specialists and discuss various professional issues.

The peculiarity of this organizational and pedagogical condition we have proposed is that it combines forms of learning that can be used both in the usual mode of educational space of the university and in the mode of distance online learning, which is now caused by a global pandemic. The combination of these forms 
will ensure the system, continuity, integrity of training and the formation of their professional culture in general and each structural component in particular.

Implementation of the following condition is as follows: combining the traditional and innovative methods of forming a professional culture is to apply in the educational space of the university traditional and innovative methods that prepare for the profession in the field of «person-person». To form the professional culture of future specialists, we used a variety of training methods that can be implemented offline and online. In particular, we propose to combine traditional teaching methods: conversation, explanation, storytelling, demonstration, etc., with the use of innovative: methods of developing critical thinking, case study, brainstorming, Bloom's chamomile, e-portfolio (e-portfolio), discussions, interactive games, acroword method, game «Coder», construction of an associative bush, interactive methods «Groening», «Cubing», use of various exercises to develop positive professional motivation: «Web of my expectations», «Circle of choice», «Tree of assumptions» and etc.; exercises for the development of professional reflection «Fishbone», technology «Six Hats», «Logic Chain», «Carousel» and others. The use of which ensures each structural component formation of the professional culture of the future specialist in the educational space of the university.

Since the global pandemic has made its modifications in the organization of the educational process of higher education, during the period of distance learning online,we used a variety of platforms for teaching students and the formation during the learning process their professional culture: Meet was used for lectures, webinars, discussions; Moodle system was developed for the organization of the educational process of Chernivtsi National University; Classroom is a learning platform through which students present their practical tasks, models, presentations; work with corporate mail @chnu.edu.ua, Google forms, Google documents provided feedback to students.

Next condition implementing self-educational activities of the future specialist on the formation of professional culture is the fulfilment of self-education by future professionals on their professional culture formation.

In reference sources, the «self-education» concept is considered as an independent way to acquire knowledge in a particular field of science; independent human cognitive activity aimed at achieving certain personal significant educational and cultural goals: the satisfaction of general cultural needs, cognitive interests in any field of activity [3]. Self-education is a condition of personal development, selfaffirmation and self-realization and is a component of lifelong learning.

This condition is realized only when the future specialists have formed such components of professional culture as a system of professional values, positive professional motivation, professional competence, professional reflection. Also, active cognitive activity, self-awareness, desire to self-develop and self-improvement should be formed in students, only such factors determine the implementation of this organizational and pedagogical condition.

In our study, introducing this condition for the formation of professional culture of future specialists in the educational space of the university, we offered students to 
keep an individual plan for the professional culture formation, in which they noted knowledge, professional qualities that would like to be improved, develop, enlarge; topics of interest to students, forms of work in which they planned to participate in the framework of self-education were indicated. Also, implementing this organizational and pedagogical condition, we used techniques aimed at internal mechanisms of future specialists' self-development: self-knowledge, selfdetermination, self-education, self-affirmation, self-expression, etc.

Discussion. There was put in practice an experimental study among students of professions in the area of «person-person» system and the effectiveness of the proposed organizational and pedagogical conditions for the formation of professional culture of the future specialist in the educational environment of the university. Summary of the results about the experiment are clearly illustrated in Figure 1.

The level of formation of the future specialists professional culture in the educational space of the university

(after the experiment $(\%)$ )

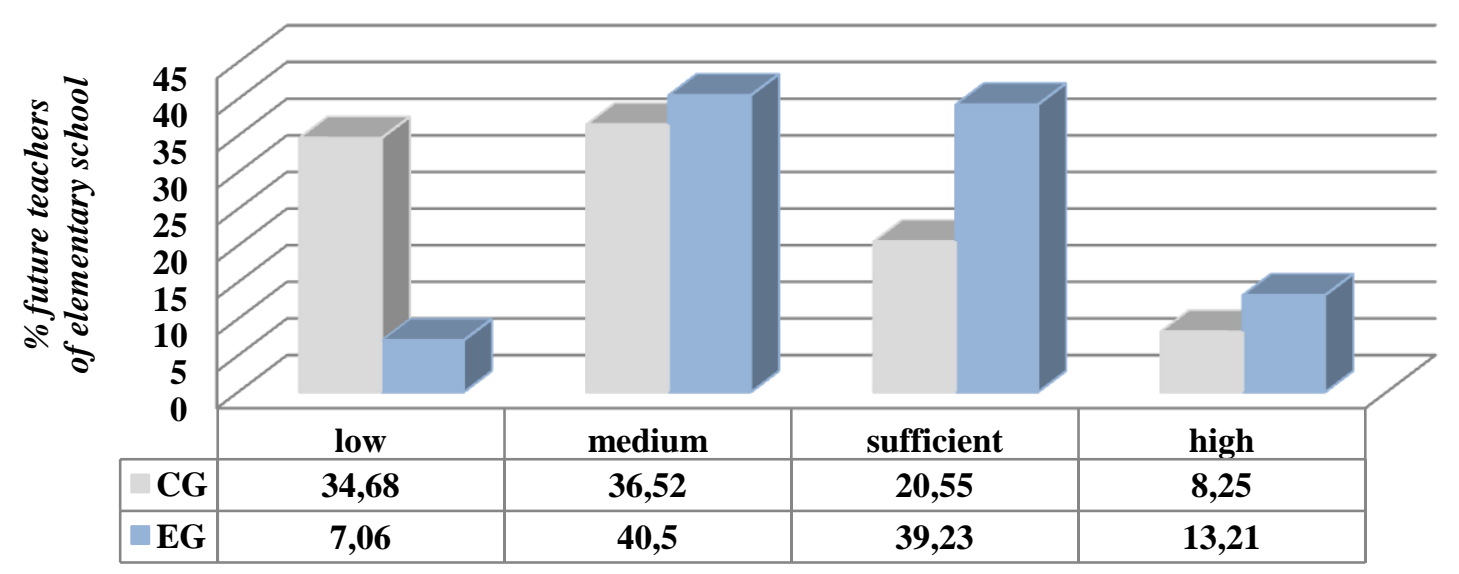

\section{Fig. 1. Levels of future specialist professional competence formation in the educational space of the university according to the results of the experiment}

The analysis of the obtained results shows that the percentage of EG students with a high level $(+7,19 \%)$, sufficient $(+18,59 \%)$ and average $(+6,94 \%)$ levels of formation of specialists'professional cultureincreased, while with a low level it decreased $(-32,7 \%)$. The corresponding indicators of CG students did not change significantly.

The reliability of the generalized results was checked using Pearson's criterion: $\chi^{2}=\mathbf{2 5 , 5 7 3}$, the value of which exceeds the critical value, which confirms the hypothesis of the study.

Conclusions. The formation in the future specialists professional culture in the educational space of the university is a purposeful influence on the individual in order to develop and improve its value orientations, professional qualities, knowledge, skills and abilities, the ability to maintain effective professional activities. This process is complex, multifaceted, pedagogically oriented, characterized by manageability, organization, predictability and completeness of results and is considered from the standpoint of cultural science, axiological, competence, systemic 
and personal and activity scientific approaches. It is defined that the «specialists' professional culture» is a combination of professional and personal values and qualities of the individual, the professional competence, which ensure highly effective performance of professional duties based on reflection and selfdevelopment. Its structural components are: value, cognitive, personal and reflexive components. It is proved that increasing the levels of professional culture of future specialists in the educational space of the university will be effective in the implementation of the proposed and experimentally tested organizational and pedagogical conditions.

\section{Author contributions. The authors contributed equally. \\ Disclosure statement. The authors do not have any conflict of interest. References:}

1. Bibler, V. S.(1989). Dialog of Cultures (Experience of Definition).Issues of Philosophy, 6, 32-42 [in Ukrainian].

2. Boychuk, Yu. D. (2010).Theoretical and methodological bases of ecological and valeological culture formation of the future teacher.(Author's dissertation of Doctor of Pedagogical Sciences). G. S. Skovoroda Kharkiv National Pedagogical University, Kharkiv [in Ukrainian].

3. Busel, W. T. (Ed.). (2009). Large explanatory dictionary of the modern Ukrainian language.Kyiv, Irpin: Perun [in Ukrainian].

4. Caton, M. P. (1950). Agriculture. Moscow, Leningrad: USSR Academy of Sciences [in Russian].

5. Cicero, M. T. (1825). Tusculanarum Quaestionum ad M. Brutum. Wien, Triest: Geistinger [in English].

6. Fernando M., Andreas Schleicher, (2020). Aframe work to guide an education response to the COVID-19 Pandemic of 2020 URL: https://www.hm.ee/sites/default/files/framework_guide_v1_002_harward.pdf [in English].

7. Filipchuk, G. G. (2014) Nation-building of education. Chernivtsi: Zelena Bukovyna [in Ukrainian].

8. Gerasymchuk, A., Palekha, Y. \&Shyyan, O. (2004).Sociology. Kyiv: European University [in Ukrainian].

9. Isayev, I. F. (2010). Professional-Pedagogical Cultureas an Object of Scientific Research.Theoretical Issues of Culture, Education and Upbringing. 42, 143-147.URL: http://nbuv.gov.ua/UJRN/Tpkov_2010_42_40 [in Ukrainian].

10. Karpov, A. V. (2003). Reflexivity as a mental property and methods of its diagnosis.Psychological Journal, 24 (5), 45-57 [in Ukrainian].

11. Khomych, L. O. (1998). Professional and pedagogical training of primary school teachers - K .: «Master - S». - 200 s. [in Ukrainian].

12. Klimova, E. A (Ed.).(1999). Psychological diagnostics in personnel management. Moscow: RPO [in Russian].

13. Kornienko, O. M. (1998). National values of the individual: the essence and features of formation. (Author's dissertation of Candidate of Philosophical Sciences). Taras Shevchenko Kyiv University, Kyiv [in Ukrainian].

14. Kroeber, A. L., Kluckhohn, C. (1952). Culture a critical review of concepts and definitions. Cambridge, Massachusetts. URL: http://www.pseudology.org/Psyhology/CultureCriticalReview1952a.pdf [in English].

15. Krylova, N. B. (1990), Formation of the future specialist's culture.M .: Higher School [in Ukrainian].

16. Law (2014). On higher education. (2014). URL: http://zakon2.rada.gov.ua/laws/show/1556-18

17. Law (2017). On education. URL: http://zakon3.rada.gov.ua/laws/show/2145-19

18. Markaryan, E. S. (1983). Theory of culture and modern science: Logic-methodological analysis. Moscow: Mysl [in Russian].

19. Nichkalo, N. G. (2001). Development of research in Ukraine on the problems of pedagogy and psychology of vocational education at the turn of the century. Kyiv: Scientific World [in Ukrainian].

20. Ognevyuk, V. O. (2003) Education in the system of values of sustainable human development (worldview and methodological aspect).(Dissertation of Dr. of Ph.D.).Taras Shevchenko Kyiv National University, Kyiv [in Ukrainian].

21. Pavelkiv, R. V. (2009). General Psychology. Kyiv: Condor [in Ukrainian].

22. Petinova, O. B. (2002). The problem of value in philosophy.Culture of the peoples of the Black Sea region, 36, 183188 [in Ukrainian].

23. Popenko, O. M (2012). Teacher's professional culture as an integrative quality of a professional teacher's personality. Scientific notes of Nizhyn State University. Nikolai Gogol Psychological and pedagogical sciences,1, 4449.URL: http://nbuv.gov.ua/UJRN/Nzspp_2012_1_12 [in Ukrainian].

24. Rogov, E. I. (1999). Desktop book of a practical psychologist (Book 2). Moscow: VLADOS [in Russian].

25. Rubinstein, S. L. (1976). Man and the world. Problems of general psychologists (2nd ed.). (pp. 253-381). Moscow: Academy of Pedagogical Sciences of the RSFSR [in Russian].

26. Rybalka, V. V. (2009). Axiological bases of psychological culture of personality. Kyiv: [b.v.] [in Ukrainian].

27. Shadrikov, V. D. (1998). Psychology of human activity and abilities. Moscow: Logos [in Russian].

28. Slastyonin, V. A. (1993). Formation of teacher's professional culture.M .: Prometey [in Russian]. 
29. Sotskaya, G. I. (2011). Theoretical and methodical bases of formation of aesthetic culture of the future teacher of fine arts.Modern information technologies and innovative teaching methods in training: methodology, theory, experience, problems, 28, 472-477 [in Ukrainian].

30. Tanchyn, I. Z. (2007). Sociology (2nd ed.). Kyiv: Znanya [in Ukrainian].

31. Tarasenko, T. V (2014) Formation of the future teachers'professional culture of philological specialties in the process of studying professional disciplines. (Author's dissertation of Candidate of Pedagogical Sciences).Vlolodymyr Vynnychenko Kirovograd State Pedagogical University, Kirovograd [in Ukrainian].

32. Tereshchuk, G. V. (Ed.). (2007). Formation of professional culture of a teacher in the context of Ukraine's integration into the European educational space, Materials of a regional scientific-practical seminar. Ternopil: TNPU named after V. Hnatyuk [in Ukrainian].

33. UNESCO, Press Service,(2010). UNESCO rallies international organizations, civil society and private sector partners in a broad Coalition to ensure URL: https://en.unesco.org/covid19/educationresponse/globalcoalition [in English].

34. Ziaziun, I. A. (2009).Axiological milestones of modern culture.Collection of materials of an international scientific and practical conference.(C. I, http://lib.iitta.gov.ua/3509/1/\%D0\%B7\%D1\%8F\%D0\%B7\%D1\%8E\%D0\%BD4.pdf [in Ukrainian].

35. Zlobin, N. S. (1980). Culture and social progress. Moscow: Nauka [in Russian]. 